\title{
A Novel, Nonpeptidic, Orally Active Bivalent Inhibitor of Human $\beta$-Tryptase
}

\author{
Sarah F. Giardina ${ }^{a}$ Douglas S. Werner ${ }^{b, c}$ Maneesh Pingle ${ }^{a-c}$

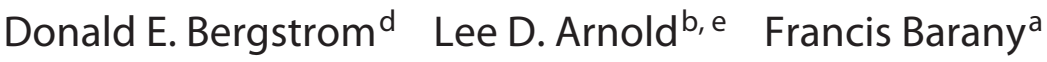

a Department of Microbiology and Immunology, Joan and Sanford I. Weill Medical College of Cornell University,

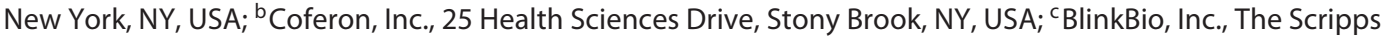
Research Institute, Jupiter, FL, USA; ${ }^{d}$ Department of Medicinal Chemistry and Molecular Pharmacology, Purdue University, West Lafayette, IN, USA; ${ }^{~}$ Fount Therapeutics, LLC, Wilmington, DE, USA

\section{Keywords}

$\beta$-Tryptase · Bivalent inhibitor · X-ray analysis · Disiloxane $\cdot$ Tight-binding $\cdot$ Protease inhibitors

\begin{abstract}
$\beta$-Tryptase is released from mast cells upon degranulation in response to allergic and inflammatory stimuli. Human tryptase is a homotetrameric serine protease with 4 identical active sites directed toward a central pore. These active sites present an optimized scenario for the rational design of bivalent inhibitors, which bridge 2 adjacent active sites. Using (3-[1-acylpiperidin-4-yl]phenyl)methanamine as the pharmacophoric core and a disiloxane linker to span 2 active sites we have successfully produced a novel bivalent tryptase inhibitor, compound $1 \mathrm{a}$, with a comparable profile to previously described inhibitors. Pharmacological properties of compound 1 a were studied in a range of in vitro enzymic and cellular screening assays, and in vivo xenograft models. This non-peptide inhibitor of tryptase demonstrated superior activity $\left(\mathrm{IC}_{50}\right.$ at $100 \mathrm{pmol} / \mathrm{L}$ tryptase $\left.=1.82 \mathrm{nmol} / \mathrm{L}\right)$ compared to monomeric modes of inhibition. X-ray crystallography
\end{abstract}

\section{KARGER}

(C) 2018 S. Karger AG, Basel

E-Mail karger@karger.com

www.karger.com/pha validated the dimeric mechanism of inhibition, and 1a demonstrated good oral bioavailability and efficacy in HMC-1 xenograft models. Furthermore, compound 1a demonstrated extremely slow off rates and high selectivity against-related proteases. This highly potent, orally bioavailable and selective inhibitor of human tryptase will be an invaluable tool in future studies to explore the therapeutic potential of attenuating the activity of this elusive target. $\odot 2018 \mathrm{~s}$. Karger AG, Basel

\section{Introduction}

Mast cells, immune cells that play central roles in innate and adaptive immunity, can be activated by IgE-dependent and - independent mechanisms to release mediators such as tryptase, cytokines, and histamine [1-4]. The tryptase family of proteases are divided by their amino acid sequence into 4 types, $\alpha, \beta, \delta$ and $\gamma$ [5-8]. $\beta$-Tryptase, the most abundant protein in human mast cells, is stored at quantities as high as 15-30 pg/cell [9], and is hereafter is referred to as tryptase. Tryptase is en- 
zymatically active in a non-covalently linked tetramer form which is stabilized with negatively charged aminoglycans such as heparin and high ionic strength $[5,10]$. The active sites of tryptase, while are similar to the structure of trypsin, are arranged in a tetrameric state that are directed toward a central pore, which possesses 2 narrow openings of $\sim 40 \AA \times 15 \AA[6,10]$, restricting the access of substrates and inhibitors.

Direct evidence for a key role of tryptase proteolytic activity in inflammatory responses has been found in asthma [5, 11, 12], colitis [13], and arthritis [14, 15], where it plays a number of roles including the destruction of bronchodilators and peptides, propagation of mast cell degranulation, regulation of inflammatory cytokines, fibroblast and smooth muscle growth, extracellular matrix degradation and remodeling, recruitment of inflammatory cells, and activation of protease-activated receptor 2 on vasculature, eosinophils, keratinocytes, and neurons. Tryptase is believed to play important roles in the pathophysiology of smoke-induced emphysema, lung fibrosis and chronic obstructive pulmonary disease [16-18]. In experimental models of colitis and arthritis, the knockout of tryptase activity greatly reduces the severity of disease and the number of inflammatory infiltrates $[13,14]$ that contribute to hypersensitivity symptoms [19] and barrier dysfunction [20].

Support for the use of tryptase inhibitors for the therapeutic benefit in allergic rhinitis [21], asthma [12, 22, 23], and colitis [24] has been produced in early clinical trials. In vitro, tryptase has been shown to cause mast cell degranulation [25], eosinophil and neutrophil migration [26], inactivation of fibrinogen [27], and amplification of histamine responses [28]. Recently, tryptase has been implicated in scar formation [29,30], hepatic fibrosis [31], chronic pain associated with prostatitis [32], and irritable bowel syndrome [20]. Nafamostat, a potent, but poorly specific inhibitor of tryptase, has shown efficacy in reducing intestinal inflammation in preclinical models, and in colitis patients refractory to corticosteroids or sulfasalazine [33-35]. Inhibition of tryptase reduces protease-activated receptor 2 activation and decreases collagen content and subsequent hepatic fibrosis scores in rat models [31], suggestive of a possible therapeutic pathway for fibrotic disease. A correlation between mast cell density, VEGF mediated angiogenesis and tumor development has been reported [36-38]. In addition to using tryptase serum levels as a marker for surgery guidance in cancer patients, it has been suggested that tryptase inhibitors may be useful in adjuvant treatment in highly angiogenic tumors [37, 39]. Despite recent advances, clear therapeutic roles for tryptase in these pathophysiological conditions are still somewhat speculative, in part due to the lack of potent, selective, and bioavailable pharmaceuticals.

Despite over 20 years of research, no viable tryptase inhibitor has been successfully approved for clinical use [5]. Inhibitors can be categorized into those that form covalent bonds with the catalytic serine [40], and those that contain a $\mathrm{P} 1$ group that forms $\mathrm{H}$-bonding interactions with Asp189 in the S1 pocket [41-43]. Targeting the catalytic serine presents problems with selectivity, whereas targeting the P1 group requires a strong basic group and has typically led to molecules with poor bioavailability. Designing bivalent inhibitors for neutral P1 groups has failed to generate any binding to tryptase [44]. Some inhibitors have reached phase II clinical trials in allergy, asthma, and colitis. While the peptidomimetic inhibitor, APC366 lacked high potency and selectivity [45], and bivalent APC1390 did not have ideal drug-like properties, both were somewhat effective in treating asthma in clinical trials. APC366 did not progress in the clinic due to its slow acting nature, low efficacy, and lack of specificity [46]. The second generation, an injectable bivalent tryptase inhibitor, APC2059, had improved pharmacokinetics, reached phase II clinical trials in ulcerative colitis and psoriasis $[24,46,47]$ but was not developed further due to limited success. Similar evidence supporting a key role for tryptase has emerged from clinical trials conducted in allergic rhinitis [21].

In this study, we introduced a novel bivalent tryptase inhibitor using a disiloxane linker moiety with oral bioavailability, high specificity, and extremely slow off rates. Our novel inhibitor is compared to a previously described bivalent tryptase inhibitor, compound 2 [44], referred to as compound $2 \mathrm{a}$ in the present manuscript, and the broad spectrum serine protease inhibitor, nafamostat [34, 48]. We anticipate that this compound will become an invaluable tool to help decipher the important roles of tryptase as a target for therapeutic interventions against inflammatory and allergic diseases.

\section{Methods}

Synthesis of Compound $1 a$ and Compound $1 b$

To facilitate the design, exploration, and development of linker chemistries for inhibition of tryptase, we used (3-[1-acylpiperidin4-yl]phenyl)methanamine as the pharmacophoric core. Variants of this pharmacophore produce monovalent tryptase inhibitors with the N1-acyl moieties bound proximally in adjacent catalytic subunits and a range of potencies $(10 \mathrm{nmol} / \mathrm{L}-1 \mu \mathrm{mol} / \mathrm{L})[44,49]$. 
Structures of compounds used in the current study are shown in online supplemental Figure S1 (for all online suppl. material, see www.karger.com/doi/10.1159/000492078).

\section{Scheme 1: Synthesis of $1 \mathrm{a}$ and $1 \mathrm{~b}$}

Tert-Butyl N-([3-[1-[3-[hydroxy[dimethyl] silyl]benzofuran5-carbonyl]-4-piperidyl]phenyl]methyl]) carbamate (1): A stirred suspension of $2(0.478 \mathrm{~g}, 0.93 \mathrm{mmol})$ in $\mathrm{N}$-methylpyrrolidine $(15 \mathrm{~mL})$ was degassed with argon then charged with $\mathrm{PdCl}_{2}(0.0164 \mathrm{~g}$, $0.09 \mathrm{mmol})$, DIEA (0.721 mL, $5.5 \mathrm{mmol}), 2$-(di-tert-butylphosphino)biphenyl (0.055 g, $0.18 \mathrm{mmol})$, and 1,2-diethoxy-1,1,2,2-tetramethyl silane $(1.15 \mathrm{~g}, 5.5 \mathrm{mmol})$ and heated to $50^{\circ} \mathrm{C}$ for $14 \mathrm{~h}$. The reaction mixture was charged with acetonitrile $(20 \mathrm{~mL}), 1 \mathrm{~N}$ aq. acetic acid $(10 \mathrm{~mL})$, and 2-(dimethylamino)ethanethiol hydrochloride $(0.264 \mathrm{~g}, 1.8 \mathrm{mmol})$ and stirred at $\mathrm{RT}$ for an additional $2 \mathrm{~h}$. The reaction mixture was diluted with $\mathrm{H}_{2} \mathrm{O}(20 \mathrm{~mL})$, filtered through a pad of celite, and the aqueous solution extracted with EtOAc $(3 \times 15 \mathrm{~mL})$. The combined EtOAc extracts were dried over anhydrous sodium sulfate, filtered, and concentrated in vacuo resulting in $1.1 \mathrm{~g}$ of crude product, which was further purified by chromatography on silica gel (230-400 mesh; eluting with $40 \%$ EtOAc in n-hexane), resulting in $0.390 \mathrm{~g}$ ( $35 \%$ yield) of 3 as a thick oil. MS (ES+): $m / z=558.9[\mathrm{M}+\mathrm{Na}]+$; HPLC: $t_{\mathrm{R}}=2.97 \mathrm{~min}$.

\section{(4-[3-[Aminomethyl]phenyl]-1-piperidyl)-(3-}

[hydroxy[dimethyl]silyl]benzofuran-5-yl) methanone

(Compound 1a)

A solution of $3(0.39 \mathrm{~g}, 0.76 \mathrm{mmol})$ in DCM $(20 \mathrm{~mL})$ was charged with TFA $(3.9 \mathrm{~mL})$ and stirred at RT for $1 \mathrm{~h}$. The mixture was concentrated in vacuo and the crude product was purified by preparative HPLC resulting in $20 \mathrm{mg}$ (6.22\% yield) of compound $1 \mathrm{la}$ as a white solid. $1 \mathrm{HnMR}(400 \mathrm{MHz}$, DMSO-d6, D2O): $\delta=8.00$ $7.92(\mathrm{~m}, 1 \mathrm{H}), 7.69-7.60(\mathrm{~m}, 2 \mathrm{H}) 7.42-7.23(\mathrm{~m}, 4 \mathrm{H}), 4.00(\mathrm{~s}, 2 \mathrm{H})$, $2.93-2.71(\mathrm{~m}, 4 \mathrm{H}), 2.81(\mathrm{t}, \mathrm{J}=59.7 \mathrm{~Hz}, 1 \mathrm{H}), 1.83-1.61(\mathrm{~m}, 4 \mathrm{H}), 0.40$ (s, 6H); 13CnMR (100 MHz, DMSO-d6): $\delta=169.0$ (-CON-), 155.2, 152.3, 145.6, 131.2, 129.9, 128.4, 126.7, 126.0, 123.4, 120.5, 114.5 ( $\mathrm{Ar}), 111.2$ (-C-Si-), $43.1\left(-\mathrm{CH}_{2} \mathrm{NH}_{2}\right), 41.7\left(-\mathrm{CH}_{2} \mathrm{~N}-\right), 40.1$ $\left(-\mathrm{C}-\mathrm{CH}_{2}{ }^{-}\right), 38.8\left(-\mathrm{CH}_{2}-\mathrm{C}-\right), 1.3(-\mathrm{SiMe}) ; \mathrm{MS}(\mathrm{ES}+): \mathrm{m} / z=408.95$ $[\mathrm{M}+\mathrm{H}]+$ (monomer), $799.45[\mathrm{M}+\mathrm{H}]+$ (dimer); HPLC: $t_{\mathrm{R}}=$ 1.75 min (monomer), 2.07 min (dimer); HRMS $(\mathrm{m} / z)$ : $[\mathrm{M}]+\mathrm{cal}-$ culated for $\mathrm{C}_{46} \mathrm{H}_{54} \mathrm{~N}_{4} \mathrm{O}_{5} \mathrm{Si}_{2}$, 799.3679; found, 799.3713 .

(4-[3-[Aminomethyl]phenyl]-1-piperidyl)-(3-

bromobenzofuran-5-yl)methanone (Compound $1 b$ )

A solution of $2(0.05 \mathrm{~g}, 0.09 \mathrm{mmol})$ in DCM $(5 \mathrm{~mL})$ was charged with TFA $(0.5 \mathrm{~mL})$ and stirred at RT for $1 \mathrm{~h}$. The reaction mixture was concentrated in vacuo and the crude product was purified by preparative HPLC resulting in $15 \mathrm{mg}$ (37.5\% yield) of compound $1 \mathrm{~b}$ as a brown oil. $1 \mathrm{HnMR}\left(400 \mathrm{MHz}, \mathrm{DMSO}-\mathrm{d} 6, \mathrm{D}_{2} \mathrm{O}\right): \delta \delta=8.27$ $(\mathrm{s}, 1 \mathrm{H}), 7.72(\mathrm{~d}, \mathrm{~J}=8.8 \mathrm{~Hz}, 1 \mathrm{H}), 7.55(\mathrm{~s}, 1 \mathrm{H}), 7.46(\mathrm{~d}, \mathrm{~J}=8.8$ $\mathrm{Hz}, 1 \mathrm{H}), 7.32-7.36(\mathrm{~m}, 4 \mathrm{H}), 4.62$ (bs, $1 \mathrm{H}), 3.97(\mathrm{~s}, 2 \mathrm{H}), 2.66-3.17$ $(\mathrm{m}, 4 \mathrm{H}), 1.53-1.82(\mathrm{~m}, 4 \mathrm{H})$; MS $(\mathrm{ES}+): m / z=413.10[\mathrm{M}+\mathrm{H}]+$, $415.10[\mathrm{M}+\mathrm{H}] 2+$; HPLC: $t_{\mathrm{R}}=1.83 \mathrm{~min}, \operatorname{HRMS}(\mathrm{m} / z)$ : $[\mathrm{M}]+\mathrm{calcu}-$ lated for $\mathrm{C}_{21} \mathrm{H}_{21} \mathrm{BrN}_{2} \mathrm{O}_{2}$, 413.0865; found, 413.0831 .

\section{Tryptase Inhibition Screening in vitro}

$\beta \mathrm{II}$ tryptase was incubated with compounds at RT for $3 \mathrm{~h}$ at $1.2 \times$ their final concentration in assay buffer $(50 \mathrm{mmol} / \mathrm{L}$ HEPES, $150 \mathrm{mmol} / \mathrm{L} \mathrm{NaCl}, 100$ mol/L EDTA, pH 7.4), with subsequent dilution into assay buffer containing a final concentration of
$200 \mu \mathrm{mol} / \mathrm{L}(2 \times \mathrm{Km})$ N-tert-butoxycarbonyl-Gln-Ala-Arg-AMC (Enzo Life Sciences). A final concentration of $10 \mathrm{pmol} / \mathrm{L}-1 \mathrm{nmol} / \mathrm{L}$ tryptase, calculated for the monomer from the average molecular weight, was used. The release of AMC was immediately measured every $30 \mathrm{sec}$ for $15 \mathrm{~min}$ at Ex.: $367 \mathrm{~nm}$, Em.: $468 \mathrm{~nm}$ on a Spectramax M5 (Molecular Devices) microplate reader. The Softmax Pro (Molecular Devices) and GraphPad Prism 6 software were used to determine $\mathrm{VMax}$ and $\mathrm{IC}_{50} \mathrm{~s}$, respectively.

\section{Determination of Kinetic Curvature}

Inhibitors were preincubated with $200 \mu \mathrm{mol} / \mathrm{L}$ substrate for approximately $5 \mathrm{~min}$. The hydrolysis of AMC was immediately measured after the addition of tryptase every $5 \mathrm{sec}$ for $30 \mathrm{~min}$, as described above.

\section{Tryptase Reversibility Studies}

Bound inhibitors $(10 \mu \mathrm{mol} / \mathrm{L})$ to tryptase $(100 \mathrm{nmol} / \mathrm{L})$ were separated from unbound using $7 \mathrm{kD}$ cut-off Zeba desalting columns (Pierce), which had been equilibrated with $1 \mathrm{~mol} / \mathrm{L} \mathrm{NaCl}$ immediately prior to use. The subsequent eluant was diluted 1:100 in assay buffer and monitored over $216 \mathrm{~h}$ for tryptase activity as described above.

\section{Protease Selectivity Studies}

Selectivity for tryptase over trypsin, kallikrein, thrombin, plasmin, and factor XA was evaluated using $1 \mathrm{nmol} / \mathrm{L}$ of each enzyme and substrates at concentrations $2 \times \mathrm{Km}$. Kinetic reads were measured over $15 \mathrm{~min}$ with the following substrates and settings: Kallikrein, $150 \mu \mathrm{mol} / \mathrm{L}$ H-D-Val-Leu-Arg-AFC Ex: $400 \mathrm{~nm}$ Em: $505 \mathrm{~nm}$; Thrombin, $100 \mu \mathrm{mol} / \mathrm{L}$ Benzoyl-FVR-AMC Ex: $367 \mathrm{~nm}$ Em: 468 nm; Plasmin, $700 \mu \mathrm{mol} / \mathrm{L}$ H-D-Val-Leu-Lys-pNA-2HCl absorbance $405 \mathrm{~nm}$; trypsin, $150 \mu \mathrm{mol} / \mathrm{L} \mathrm{N}$-tert-butoxycarbonylGln-Ala-Arg-AMC Ex: $367 \mathrm{~nm}$ Em: $468 \mathrm{~nm}$; Factor XA, $700 \mu \mathrm{mol} / \mathrm{L}$ N-tert-butoxycarbonyl-Gln-Ala-Arg-AMC Ex: 367 nm Em: $468 \mathrm{~nm}$.

\section{Inhibition of Cellular Tryptase in HMC-1 Cells}

HMC-1 cells were a gift from Dr. J. H. Butterfield (Mayo Clinic, Rochester, MN, USA) [50]. Cultures of HMC-1 cells were grown at $37^{\circ} \mathrm{C}, 5 \% \mathrm{CO}_{2}$, in Iscove's modified Dulbecco's medium (Life Technologies), supplemented with $36 \mathrm{mmol} / \mathrm{L}$ sodium bicarbonate, $1.2 \mathrm{mmol} / \mathrm{L}$ monothioglycerol (Sigma-Aldrich), 10\% Normal Calf Serum (Life Technologies), $100 \mathrm{U} / \mathrm{mL}$ penicillin and $100 \mu \mathrm{g} / \mathrm{mL}$ streptomycin. Cells were treated with inhibitors (10 nmol/L-100 $\mu \mathrm{mol} / \mathrm{L} ; 2 \mathrm{~h}$ ) and subsequently washed in PBS. Degranulation was induced with $1 \mu \mathrm{mol} / \mathrm{L}$ A23187 in PBS. After $1 \mathrm{~h}$ the supernatant was assayed for tryptase activity as described above. Alternatively, treated cells were lysed in buffer (assay buffer containing $0.1 \%$ TX-100, with $1 \mathrm{mmol} / \mathrm{L}$ EDTA, $20 \mu \mathrm{g} / \mathrm{mL}$ heparin, $0.5 \mathrm{mg} / \mathrm{mL}$ soybean trypsin inhibitor, $100 \mathrm{nmol} / \mathrm{L}$ aprotinin, $0.5 \mu \mathrm{g} / \mathrm{mL}$ pepstatin, and $100 \mu \mathrm{mol} / \mathrm{L} \mathrm{N}$-Ethylmaleimide) and assayed for tryptase activity as described above.

\section{Enzyme Histochemistry for in Situ Inhibition of Tryptase}

For the evaluation of tryptase activity in situ, frozen lung tissue samples from patients with asthma (BioChain) were fixed in $4 \%$ paraformaldehyde to inhibit non-specific cleavage of the substrate and subsequently treated with compounds for $2 \mathrm{~h}$ at RT. Slides were washed in PBS and incubated with $0.25 \mathrm{mg} / \mathrm{mL} \mathrm{z}$-Ala-AlaLys-4-methoxy-2-naphthylamide (Enzyme System Products) in 
$0.1 \mathrm{~mol} / \mathrm{L}$ phosphate buffer, $\mathrm{pH} 7.5$, for $20 \mathrm{~min}$ at $37^{\circ} \mathrm{C}$, followed by a $5 \mathrm{~min}$ wash with $1 \%$ copper sulfate [51]. Slides were dehydrated, mounted, and were visualized using bright-field microscopy. Images are representative of $n=10$ across $2-3$ independent experiments.

\section{Pharmacokinetics in Mice}

Pharmacokinetics was determined in freely feeding male C57BL/6 mice following single intravenous doses $(10 \mathrm{mg} / \mathrm{kg}$ dose, $2 \mathrm{mg} / \mathrm{mL}$ solution in $0.9 \%$ sterile saline) and oral (10 and $100 \mathrm{mg} / \mathrm{kg}$ at 1 and $10 \mathrm{mg} / \mathrm{mL}$ solutions in water, respectively). Blood samples were collected under isoflurane anesthesia and samples were obtained at pre-dose, $0.08,0.25,0.5,1,2,4,8$ and $24 \mathrm{~h}$ (i.v.) and pre-dose, $0.25,0.5,1,2,4,6,8$ and 24 h (p.o.) using dipotassium EDTA as anticoagulant. Plasma samples were treated with 3 volumes of acetonitrile, vortexed, chilled on ice ( $1 \mathrm{~h})$, and centrifuged. Drug levels in supernatant were analyzed by LCMS/MS using a gradient of acetonitrile in water containing $0.1 \%$ formic acid at $1 \mathrm{~mL} / \mathrm{min}$ over $5 \mathrm{~min}$ on an Agilent 1200 system equipped with an Eclipse XDB-C18 $(4.6 \times 150 \mathrm{~mm})$ column at $40^{\circ} \mathrm{C}$ with positive-ion MRM detection on an API4000-Q Trap (MDS Sciex, Applied Biosystems). Aliquots of dosing solutions were analyzed to determine actual concentrations $(2.58,0.86$, and $8.17 \mathrm{mg} / \mathrm{mL}$, for $10 \mathrm{mg} / \mathrm{kg}$ i.v., 10 and $100 \mathrm{mg} / \mathrm{kg}$ p.o., respectively). Pharmacokinetic parameters were calculated using the noncompartmental analysis tool of WinNonlin ${ }^{\circledR}$ Enterprise software (version 5.2).

\section{HMC-1 Tumor Xenografts}

HMC- 1 cells $\left(1 \times 10^{7}\right)$ were resuspended in PBS $(100 \mu \mathrm{L})$ and implanted s.c. into the right and left flanks of female nu/nu CD-1 mice (Charles River), as previously described [52]. Tumors were established for 2-4 weeks and animals were randomized into treatment groups. Saline $(0.5 \mathrm{~mL} ; n=21)$ or $1 \mathrm{a}(7.8 \mathrm{mg} / \mathrm{kg} ; n=18)$ dissolved in water $(0.5 \mathrm{~mL})$ was administered by oral gavage. $\mathrm{Na}$ famostat Mesylate $(10 \mathrm{mg} / \mathrm{kg})$ was administered intravenously. Four hours post-dose animals were euthanized, plasma was collected, and excised tumors were flash frozen. Homogenized tumors were sonicated in lysis buffer and clarified by centrifugation. The supernatant was diluted 1:100 and tryptase activity was determined as described above. The concentration of compound 1a in plasma and tumor tissue homogenates was determined by LC/ MS/MS.

\section{X-Ray Crystallography}

The protein complexes with inhibitors were formed by the addition of $1 \mathrm{mmol} / \mathrm{L}$ compound to recombinant human $\beta$-Tryptase $(1.95 \mathrm{mg} / \mathrm{mL})$. The protein-compound mixtures were incubated on ice (30 $\mathrm{min})$ and centrifuged to remove the precipitate. The cocrystallizations were setup using the vapor diffusion method. Equal volumes of the protein complex and reservoir solution $(30 \%$ PEG 1500, $100 \mathrm{mmol} / \mathrm{L}$ sodium acetate $\mathrm{pH} 4.6$ and $200 \mathrm{mmol} / \mathrm{L}$ ammonium sulfate) were mixed and subsequently incubated at $25^{\circ} \mathrm{C}$ (3-5 days). Once formed, the monocrystal was soaked for $20 \mathrm{~h}$ in solution with $30 \%$ PEG 1500, $200 \mathrm{mmol} / \mathrm{L}$ ammonium sulfate, $100 \mathrm{mmol} / \mathrm{L} \mathrm{MES} \mathrm{pH} \mathrm{5.5,} \mathrm{and} 1 \mathrm{mmol} / \mathrm{L}$ compound and flashfrozen in liquid nitrogen until x-ray diffraction.

Protein Data Bank: coordinates and structure factors for the co-crystal structure of the tryptase complex have been deposited with accession code 4MPW.

\section{Materials}

Dimeric $\beta$-tryptase inhibitor 2 (referred to as compound 2a in the current manuscript; online suppl. Figure S1) has been described [44]. Recombinant human $\beta$-tryptase from lung was purchased from Promega (Madison, WI, USA) and confirmed to be in a tetrameric state by non-denaturing Western botting and $\mathrm{x}$-ray crystallography. Trypsin was purchased from Calbiochem (San Diego, CA, USA). Kallikrein, plasmin, thrombin, H-D-Val-LeuArg-AFC, Benzoyl-FVR-AMC were purchased from EMD Millipore (Billerica, MA, USA); factor XA and N-tert-butoxycarbonylGln-Ala-Arg-AMC from Enzo Life Sciences (Farmingdale, NY, USA). H-D-Val-Leu-Lys-pNA-2 HCl was purchased from Oxford Biomedical Research (Oxford, MI, USA). Unless otherwise indicated, other reagents were from Sigma-Aldrich (St Louis, MO, USA) or Life Technologies (Grand Island, NY, USA).

\section{Animal Welfare}

All animal care and experimental investigations were in accordance with the Guide for Care and Use of Laboratory Animals published by the US National Institutes of Health and approved by the Institutional Animal Care and Use Committee at Stony Brook University.

\section{Data Analysis and Statistical Procedures}

Data are expressed as mean \pm SEM Differences between doseresponse curves were analyzed by one-way ANOVA for repeated measurements, followed by unpaired Student $t$ test. Xenograft studies were analyzed by one-way ANOVA and post hoc Tukey's multiple comparison test. Probability levels of $p<0.05$ were considered statistically significant.

\section{Results}

\section{Disiloxane-Based Dimers Afford Dramatic \\ Improvements in Potency}

The dimethylsilanol (-SiMe2OH; DMS) linker was investigated, as it contributed nominal increases in molecular weight, H-bond donors/acceptors, rotatable bonds, polar surface area, and lipophilicity. Synthetic methodologies [53] and other conventional methods for installing an aliphatic DMS, producing tryptase inhibitors, which spontaneously dimerized upon lyophilization (compound 1a: 84.9-90.2\% dimer at synthesis).

Compound 1a exhibited extraordinary improvements in apparent $\mathrm{IC}_{50} \mathrm{~s}$ over its corresponding monomeric analog, with $\mathrm{IC}_{50} \mathrm{~s}$ decreasing with tryptase concentration, as anticipated with tight-binding inhibitors (Fig. 1b). In comparison, the potency of the monomer analogs, Compound $1 \mathrm{~b}$ and $2 \mathrm{a}$ were negligibly affected by the tryptase concentration. Compound 1a mediated tryptase inhibition was not significantly different from the previously described bivalent inhibitor, Compound $2 \mathrm{a}(\mathrm{F}[2,38]=0.25$, $p=0.86$; Fig. 1a). The disiloxane compound produced 


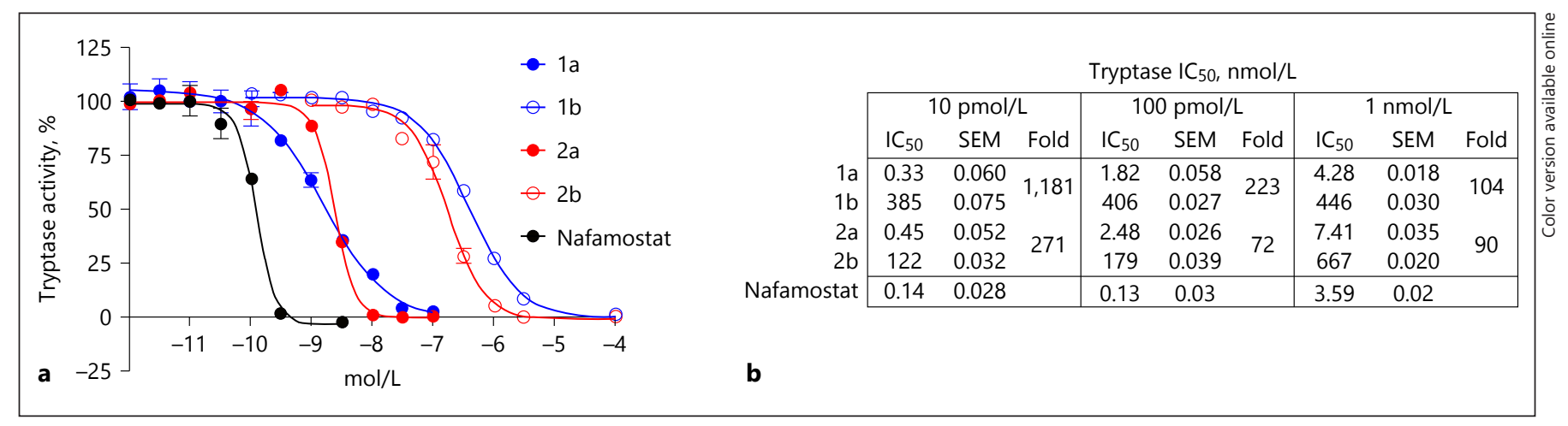

Fig. 1. a Dose-response curves for the silanol bivalent compound, $1 \mathrm{a}$, and its monomeric control, $1 \mathrm{~b}$, were compared to responses of the bivalent inhibitor, $2 \mathrm{a}$, and its monomeric analog, $2 \mathrm{~b}$. b $\mathrm{IC}_{50} \mathrm{~s}$

more potent responses at each concentration of tryptase examined and demonstrated a greater difference in potency over its monomeric analog (Fig. 1b). At $10 \mathrm{pmol} / \mathrm{L}$ tryptase the apparent $\mathrm{IC}_{50}$ of compound 1a approaches $300 \mathrm{pmol} / \mathrm{L}$, corresponding to more than a 1,000-fold improvement relative to its monomeric control.

The detailed analysis of compound la with tryptase provided a number of insights accounting for the marked potency. We confirmed the homodimeric mechanism of action via a co-crystal structure with tryptase and found that the disiloxane bridged homodimer was in a fully relaxed pose, with $\mathrm{Si}-\mathrm{O}-\mathrm{Si}$ and $\mathrm{C}-\mathrm{Si}-\mathrm{O}$ bond angles of $145^{\circ}$ and $108^{\circ}$, respectively (Fig. 2a; online suppl. Table S1) [54, 55].

\section{Compound 1a Exhibits High Affinity for Tryptase and} a Very Slow Off-Rate

A negative curvature gradually leading to a steadystate constant slope in the enzyme kinetics was observed for compound $1 \mathrm{a}$ at concentrations in the vicinity of the $\mathrm{IC}_{50}$ (Fig. $2 \mathrm{~b}$ ) suggestive of slow, albeit tight, binding. The high stability of tryptase's proteolytic activity at room temperature enabled reversibility studies of compounds to be conducted over an extended period of time. After the removal of excess unbound inhibitor from tryptase by a gel filtration spin-column, we monitored the recovery of enzymic activity. Monomeric inhibitors were readily dissociated under these conditions to immediately restore full tryptase activity, while less than $25 \%$ of activity was recovered after 9 days with compound 1a (Fig. 2c).

\section{Bivalent Inhibitor 1a is Highly Specific for Tryptase}

High specificity for tryptase among trypsin and related proteases in the coagulation cascade is essential for a potential therapeutic agent but has been challenging to and fold difference between nafamostat, the bivalent and control compounds are indicated for increasing concentrations of tryptase.

achieve with monovalent inhibitors [21, 56]. Consistent with the tailored fit of compound 1a and bivalent inhibition of tryptase, outstanding specificity was revealed by $>2,000$-fold selectivity against a panel of related trypsinfamily proteases (online suppl. Figure S2) with improvements over the monomeric analogs diminishing in parallel. Indeed, Nafamostat was found to potently inhibit other related proteases, as previously described [49], whereas the bivalent compounds were found to be only marginally more potent than their monomeric counterparts (online suppl. Figure S2).

\section{Compound la Retains Potency in the Presence}

of Plasma and its Components

As evidence of specificity and bioorthogonal behavior, the potency of compound la against tryptase was negligibly altered in the presence of plasma components including albumin (5\%), L-Glutathione (10 $\mathrm{mmol} / \mathrm{L}), \alpha$-1-acid glycoprotein $(0.1 \%)$, glucose $(8 \mathrm{mmol} / \mathrm{L})$, and marginally affected $(<8 \times)$ by the addition of $10-20 \%$ human or mouse plasma (online suppl. Table S2). Furthermore, LC/ MS/MS studies demonstrated excellent stability of compound 1a, with no evidence of decomposition after $72 \mathrm{~h}$ in plasma, or over 25 days at $\mathrm{pH} 2.1,4.7$ or 7.4.

\section{Compound 1a Permeates Cells to Effectively}

Pre-Inhibit Tryptase Prior to its Release

Tryptase is stored at high concentrations in mast cell granules and from our in vitro studies and co-crystallization efforts, the potent bivalent inhibitor retained its high affinity for tryptase even under the more acidic conditions ( $\mathrm{pH}$ 5.5-6) encountered in the storage granules. The very slow off-rate of compound $1 \mathrm{a}$ allowed us to treat HMC-1 cells with inhibitors to pre-inhibit the 


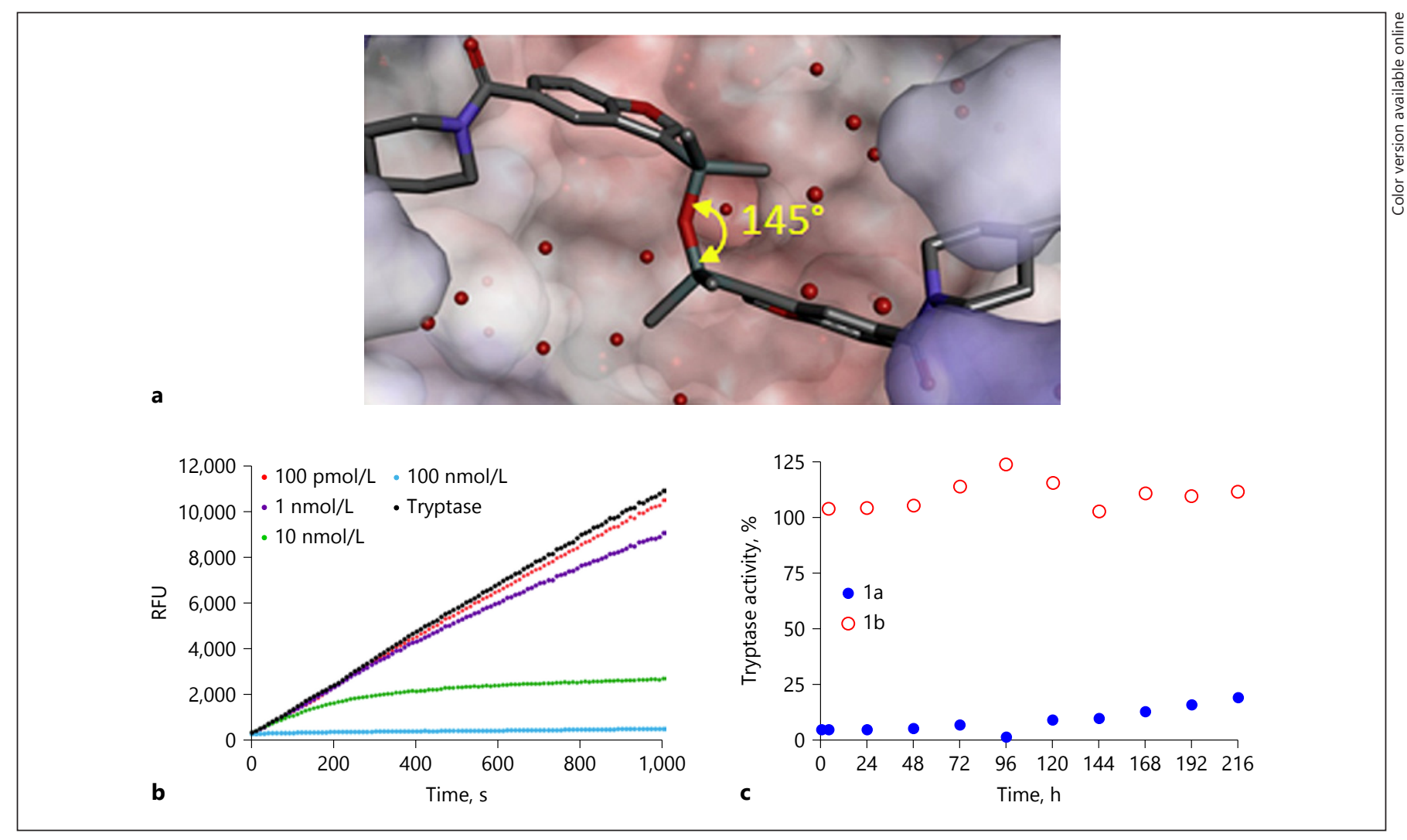

Fig. 2. a Co-crystal structures of 1 a confirmed a bivalent mechanism of inhibition, providing insights into the relaxation of the disiloxane angular deformation to $145^{\circ}$. Compound la is depicted in stick format and the protein as a surface colored by $\mathrm{pKa}$. b Curvature was observed with la in a continuous fluorimetric enzyme assay at $1 \mathrm{nmol} / \mathrm{L}$ tryptase, particularly in the vicinity of the $\mathrm{IC}_{50}$, consistent with tight binding. RFU, relative fluorescence units. c Extremely slow off-rates of the bivalent silanol were observed in reversibility studies. Tryptase $(100 \mathrm{nmol} / \mathrm{L})$ was treated with 1 a or monomer control $1 \mathrm{~b}(10 \mu \mathrm{mol} / \mathrm{L})$ and unbound inhibitor was removed by gel filtration spin column. The molar ratio of 1 a to tryptase subunits was determined to be 1.3 $( \pm 0.3): 1$ by LC-MS/MS. The subsequent solutions were diluted to 1 $\mathrm{nmol} / \mathrm{L}$ tryptase and assayed daily for tryptase activity. There was no recovery in activity without removal of excess inhibitor. target, wash, and then demonstrate a concentration-dependent inhibition of the tryptase activity (Fig. 3a). Control compounds demonstrated some inhibition in vitro, albeit more than 130 fold less potent than the bivalent compounds (Fig. 3b). Further supporting the inhibition of tryptase in mast cell granules, we observed the effective inhibition of the tryptase proteolytic activity in histochemical studies of formaldehyde-fixed sections of human asthmatic lung tissues after treatment with $100 \mu \mathrm{mol} / \mathrm{L} 1 \mathrm{a}$ but not with its monomeric analog, $4 b$ (Fig. 3c-e).

\section{Compound 1a is Orally Bioavailable and Inhibits \\ Human Tryptase Activity In Vivo}

Studies of the intravenous and oral pharmacokinetics of $1 \mathrm{a}$ at $10 \mathrm{mg} / \mathrm{kg}$ in C57BL/6 male mice revealed high oral bioavailability $(\mathrm{F}=96 \%)$, with peak plasma levels of
$650 \mathrm{nmol} / \mathrm{L}$ after oral dosing, and an i.v. elimination halflife of $5.4 \mathrm{~h}$ (Fig. 4a). A higher oral dose of $100 \mathrm{mg} / \mathrm{kg}$ safely achieved peak plasma levels of $\sim 10 \mu \mathrm{mol} / \mathrm{L}$ and sustained levels of $\sim 1 \mu \mathrm{mol} / \mathrm{L}$ for $24 \mathrm{~h}$ with no apparent adverse effects, suggesting good toleration and oral efficacy. To demonstrate in vivo efficacy of these novel inhibitors of human tryptase, bilateral human mast cell tumor (HMC-1) xenografts were grown in nude mice [52], and the TFA salt of la was administered orally at $7.8 \mathrm{mg} / \mathrm{kg}$. Tumors were excised $4 \mathrm{~h}$ post-dose, assayed for tryptase activity, and the associated levels of 1 a were determined by LC/MS/MS. 1a significantly reduced the tryptase proteolytic activity within the tumors of treated mice by $61 \%( \pm 5.8 ; \mathrm{F}[2,44]=$ $5.160, p=0.0097$ ), with associated mean plasma and tumor tissue levels of 10 and $13 \mathrm{nmol} / \mathrm{L}$ respectively (Fig. $4 \mathrm{~b}$ ). The magnitude of the inhibition at this concentration is comparable to that of the potent, nonspecific, irreversible pro- 
Fig. 3. a Tryptase activity is potently inhibited by treatment of HMC-1 cells with 1a $\left(\mathrm{IC}_{50}=58 \mathrm{nmol} / \mathrm{L} \pm 0.05\right)$ and $2 \mathrm{a}\left(\mathrm{IC}_{50}=44\right.$ $\mathrm{nmol} / \mathrm{L} \pm 0.05)$, followed by washing, and induction of degranulation with a calcium ionophore. Monomeric controls were more than 130 less potent than the bivalent inhibitors. b Inhibition of mast cell associated tryptase activity in formaldehydefixed human lung tissue from asthmatic patients. Fixed sections were incubated with DMSO (c), $100 \mu \mathrm{mol} / \mathrm{L} \mathrm{1a}(\mathbf{d})$, or $1 \mathrm{~b}$ (e) for $1 \mathrm{~h}$ prior to histochemical staining with a colorimetric tryptase substrate. Staining of mast cells (arrows) was completely inhibited by 1 a but not its monomeric analog $1 \mathrm{~b}$.

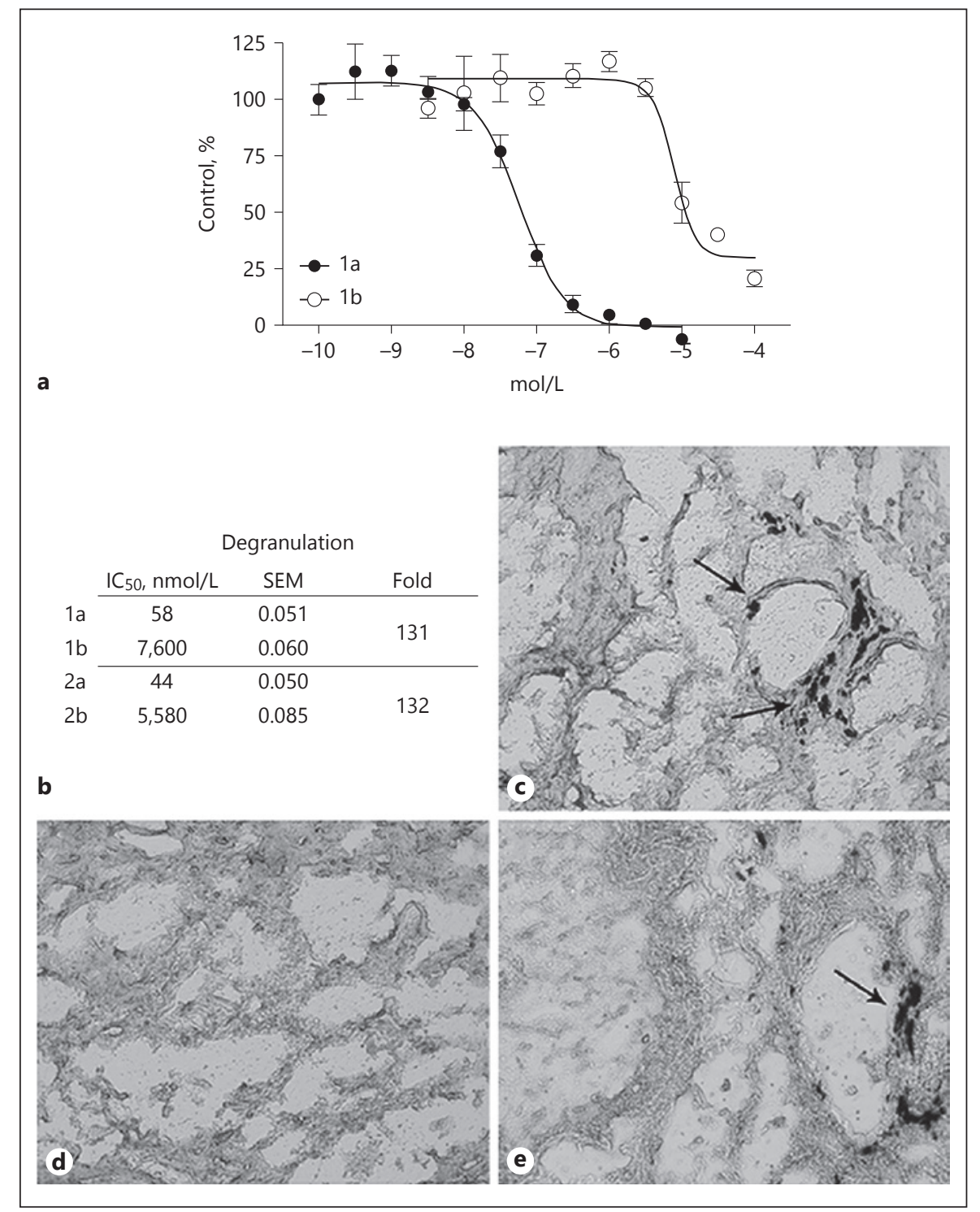

tease inhibitor, nafamostat $[34,48]$. Based upon protease activity and ELISA determinations in the tumor homogenates we estimated the intratumoral tryptase concentrations to be $3-75 \mathrm{nmol} / \mathrm{L}$, suggesting we are essentially titrating the enzyme in the tumor tissue.

\section{Discussion}

We sought bioorthogonal, single-bond linkers with the flexibility to conform to the demands of linking pharmacophoric sites while maintaining good drug-like properties and evading metabolism and conjugation. In earlier studies, Tacke et al. [57] installed silanol moieties in place of carbinols of known drugs, and demonstrated the retention of biological activity in vitro and in vivo, good stability, toleration, and pharmacokinetics, with resistance to dehydration and metabolism, and no detectable glucuronide conjugates. In several instances, disiloxane dimers of these silanol drug analogs were noted in the solid state and concentrated solutions, but dimers were not exploited and did not appear to contribute to the pharmacology [58]. Water-soluble disiloxanes were explored by Molnar et al. [59] as modulators of multidrug resistance and potential anticancer agents. Compound 1a demonstrated enhanced inhibition and ideal drug-like properties and was therefore investigated further. Disiloxane inhibitors were initially designed to act as monomers and dimerize upon the 


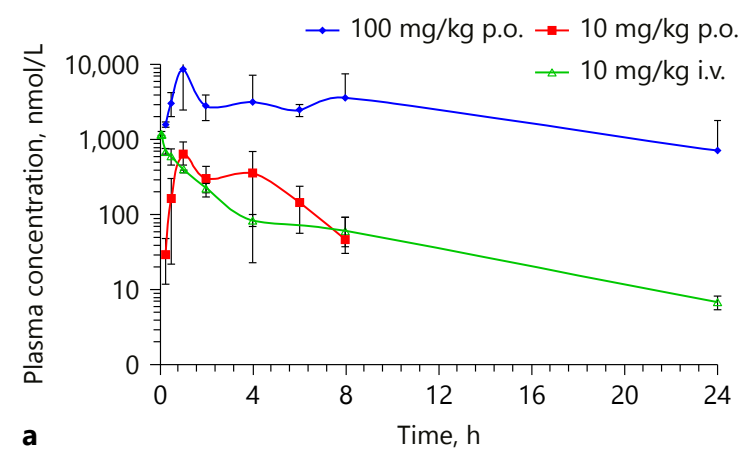

Fig. 4. a The pharmacokinetics of $1 \mathrm{a}$ as its formate salt were determined in freely feeding male C57BL/6 mice following single intravenous $(10 \mathrm{mg} / \mathrm{kg}$ in $0.9 \%$ sterile saline $)$ and oral $(10$ and $100 \mathrm{mg} / \mathrm{kg}$ in water) doses. At $10 \mathrm{mg} / \mathrm{kg}$ p.o. the oral bioavailability was $96 \%$, with peak plasma levels of $653 \mathrm{nmol} / \mathrm{L}( \pm 265)$. Only monomeric silanol was detected in all bioanalytical samples. $\mathbf{b}$ Nude mice bearing bilateral HMC1 xenograft tumors were treated orally with 1a (7.8

tryptase target [60]. However, monomerized compounds seemed unable to reform dimers under the current enzymic screening conditions in vitro and improved potencies to levels of the initial mixed homodimer solution were not observed for the duration of tryptase activity at RT (several days, data not shown). Likewise, stock solutions of compound la diluted into assay buffer did not spontaneously monomerize and the dimer concentration was consistent with that at the time of synthesis (89.4-90.2\%). The silanol dimer demonstrated remarkable oral bioavailability and efficacy, providing all the advantages of bivalent inhibition with the added benefit of oral efficacy. Analysis of the silanol compound from animals treated both by oral and intravenous administration only identified monomeric form in plasma. We found that the equilibrium shifted progressively at $\mathrm{pH} 4.7$ and 2.1 to significantly favor monomer, with rapid hydrolysis of the dimeric disiloxanes at $\mathrm{pH}$ 2.1. While possibly the orally administered dimer monomerized under the acidic conditions of the stomach, we cannot rule out the contributions of sample preparation when we consider findings from intravenous samples. Indeed, la existed primarily as dimer in the $2 \mathrm{mmol} / \mathrm{L}$ aqueous oral dosing solution and it is highly unlikely that such a magnitude of inhibition found in the xenograft studies occurred from monomeric compound. The poor thermostability of tryptase at $37^{\circ} \mathrm{Chindered} \mathrm{fur-}$ ther investigations and efforts to assess the dimer equilibrium and pharmacokinetics are beyond the scope of the current studies.

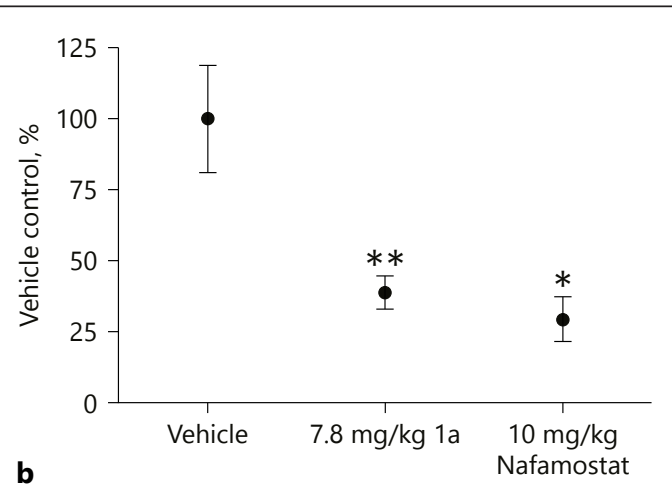

$\mathrm{mg} / \mathrm{kg}$ as TFA salt in water) or intravenously with nafamostat (10 $\mathrm{mg} / \mathrm{kg}$ i.v.). After $4 \mathrm{~h}$, tumors were excised, homogenized, and assayed for tryptase activity. 1a significantly reduced tryptase activity $(p=0.0057)$ by $61 \%( \pm 5.8)$, with mean plasma and tumor tissue levels of $4.1 \mathrm{ng} / \mathrm{mL}( \pm 1.2)$ and $5.2 \mathrm{ng} / \mathrm{mg}( \pm 2.2)$ respectively. ${ }^{*} p<0.05$, $* * p<0.01$.

The high specificity of 1 a for human tryptase was also reflected in the $\sim 20 \times$ lower potency and more modest 21 -fold effect relative to the monomeric $1 \mathrm{~b}$ observed with the mouse ortholog of human $\beta$-tryptase, despite the $>90 \%$ sequence homology in the inhibitor binding sites $\left(73 \mathrm{nmol} / \mathrm{L} \mathrm{IC}_{50}\right.$ at $2 \mathrm{nmol} / \mathrm{L} \mathrm{mMCP}-6$; online suppl. Figure S2). The most significant difference in the binding site region between human and murine tryptase is the Q117E substitution, placing glutamate sidechains of each subunit proximal to the disiloxane linkage. The effects of the acidic substitution upon the formation and stability of the bivalent inhibitor are uncertain, but one could speculate that it could accelerate the hydrolysis of bound dimer and enhance the off-rate. Therefore, to demonstrate in vivo efficacy of 1a against the target for which it was designed, human tryptase, bilateral human mast cell tumor (HMC-1) xenografts were used [52]. These studies revealed that $1 \mathrm{a}$ was able to inhibit human $\beta$-tryptase after oral administration to levels comparable to the potent, yet non-specific, Nafamostat (Fig. 4; online suppl. Figure S2).

The relevance of mast cells and their secretory products to human pathology has been the focus of significant research and has given rise to considerable efforts to develop antagonists to many of the mast cell mediators, including tryptase. Clinical trials with non-ideal candidates resulted in the discontinuance of programs, despite some early success, largely due to unwanted side effects, off target responses and lack of oral bioavailability. These fail- 
ures have also hindered progress in defining clear roles of tryptase in the many pathophysiological conditions in which it has been implicated. McNeil (2008) developed the mMCP6 knockout model and has demonstrated a direct role for this protease in arthritis [14], colitis [13], abdominal aortic aneurysms [18], and chronic obstructive pulmonary disease [16]. Indeed, tryptase might act as a novel target for the adjuvant treatment of tumors through the selective inhibition of angiogenesis [39], and the treatment of fibrotic diseases $[31,61,62]$, where current treatment options are limited. The benefits of tryptase inhibition for asthma have been demonstrated, where tryptase is thought to play a role beyond the acute airway hyperresponsiveness. Tryptase's actions as a chemoattractant for neutrophils $[13,14,16,63]$, a mitogen for fibroblasts $[61,64,65]$, and its role in tissue remodeling and repair $[22,66]$ are all points of potential therapeutic invention.

Polyvalent binding increases the affinity and specificity of interactions between molecules [67], as confirmed in the current study. Bivalent inhibitors of tryptase that engage 2 pharmacophoric binding sites spanning approximately $34 \AA$ have demonstrated more than a 1,000-fold increase in selectivity and affinity and have shown efficacy in early clinical studies $[41,68,69]$. However, these molecules possess high molecular weights, are doublecharged, and the physicochemical properties of these molecules produce poor drug-like performances [24,69]. The current study successfully developed a bivalent compound containing a disiloxane linker, which demonstrates good bioavailability after oral administration, and exhibits high selectivity and specificity.

Like previously reported dimeric inhibitors of tryptase $[24,41,44,47,69]$, compound 1a, which bridges 2 active sites, has a higher affinity for tryptase than monomeric controls [23]. Consistent with bivalent binding, we demonstrated extremely slow off rates and superior selectivity for tryptase $[23,70]$, with remarkable potencies, never seen before in orally available inhibitors of tryptase.

The prospect of selective inhibition of tryptase is of considerable pharmacological significance and therapeutic potential for allergic and inflammatory diseases. While considerable effort has been made to design selective and potent inhibitors of tryptase, to date no candidate has advanced into stage 3 clinical trials. Small molecule inhibitors have been unsuccessful due to the lack of selectivity and poor efficacy, and while larger molecules demonstrate improved potencies and selectivity but they do not have ideal drug-like properties. The current study successfully developed a bivalent inhibitor with good oral bioavailability, selectivity, and specificity for tryptase. We predict that compound 1a will be a useful pharmacological tool to help delineate the roles for tryptase in inflammatory disorders.

\section{Acknowledgments}

The authors thank T. Zimmerman and J. Rooney of Stony Brook University (DLAR) for in vivo studies with tumor-bearing mice; A. Koller and R. Rieger (Proteomics Center, Stony Brook University, NY, USA) for bioanalytical analyses. D.A. Beard (Medical College of Wisconsin) and R.C. Jackson (Pharmacometrics, UK) for kinetic and computational data analyses and discussions; Xtal BioStructures, Inc. for production of co-crystals and X-ray structure elucidation; Sai LifeScience for synthesis, equilibria analyses, and pharmacokinetic studies; Professors George H. Caughey (UCSF School of Medicine) and Lawrence B. Schwartz (VCU) for helpful discussions.

\section{Disclosure Statement}

S.F.G., L.D.A., M.P., D.E.B., and F.B. are Blinkbio Inc. shareholders. D.S.W. and M.P. are employed by Blinkbio Inc.

\section{Funding Source}

This work was supported in part by the Center for Biotechnology, an Empire State Development Division of Science, Technology and Innovation Designated Center for Advanced Technology. F.B. and S.F.G. were supported by a grant from Coferon Inc. Coferon Inc. provided compounds $1 \mathrm{a}$ and $1 \mathrm{~b}$. Bioanalytical analyses were supported under a shared instrumentation grant $(\mathrm{NIH} /$ NCRR 1 S10 RR023680-1).

\section{Author Contributions}

S.F.G. and L.D.A. contributed to study concept and design. F.B., D.E.B., M.P., and L.D.A. developed the Coferon concept and linker chemistries. D.S.W. performed and oversaw syntheses. Acquisition of data: S.F.G. Analysis and interpretation of data: S.F.G., L.D.A., D.W.S. S.F.G. and D.S.W. wrote the manuscript. All authors approved of the final version.

References

1 Bradding P, Feather IH, Wilson S, Bardin PG, Heusser CH, Holgate ST, Howarth PH: Immunolocalization of cytokines in the nasal mucosa of normal and perennial rhinitic subjects. The mast cell as a source of IL-4, IL-5, and IL-6 in human allergic mucosal inflammation. J Immunol 1993;151:3853-3865.

2 Reed CE, Kita H: The role of protease activation of inflammation in allergic respiratory diseases. J Allergy Clin Immunol 2004;114:997-1008. 
3 Schwartz LB: Mast-cells - function and contents. Curr Opin Immunol 1994;6:91-97.

4 Munitz A, Piliponsky AM, Levi-Schaffer F: IgE-independent activation of human mast cells indicates their role in the late phase reaction of allergic inflammation. Cell Tissue Bank 2003;4:25-28.

5 Caughey GH: Mast cell proteases as pharmacological targets. Eur J Pharmacol 2016;778: 44-55.

6 Pereira PJ, Bergner A, Macedo-Ribeiro S, Huber R, Matschiner G, Fritz H, Sommerhoff $\mathrm{CP}$, Bode W: Human beta-tryptase is a ringlike tetramer with active sites facing a central pore. Nature 1998;392:306-311.

7 Fiorucci L, Ascoli F: Mast cell tryptase, a still enigmatic enzyme. Cell Mol Life Sci 2004;61: 1278-1295.

8 Huang C, Li L, Krilis SA, Chanasyk K, Tang Y, Li Z, Hunt JE, Stevens RL: Human tryptases alpha and beta/II are functionally distinct due, in part, to a single amino acid difference in one of the surface loops that forms the substrate-binding cleft. J Biol Chem 1999;274: 19670-19676.

9 Schwartz LB, Lewis RA, Austen KF: Tryptase from human pulmonary mast cells. Purification and characterization. J Biol Chem 1981; 256:11939-11943.

10 Sommerhoff CP, Bode W, Pereira PJ, Stubbs MT, Stürzebecher J, Piechottka GP, Matschiner G, Bergner A: The structure of the human betaII-tryptase tetramer: fo( $\mathrm{u}) \mathrm{r}$ better or worse. Proc Natl Acad Sci U S A 1999;96: 10984-10991.

11 Brightling CE, Bradding P, Symon FA, Holgate ST, Wardlaw AJ, Pavord ID: Mast-cell infiltration of airway smooth muscle in asthma. N Engl J Med 2002;346:1699-1705.

12 Cairns JA: Inhibitors of mast cell tryptase beta as therapeutics for the treatment of asthma and inflammatory disorders. Pulm Pharmacol Ther 2005;18:55-66.

13 Hamilton MJ, Sinnamon MJ, Lyng GD, Glickman JN, Wang X, Xing W, Krilis SA, Blumberg RS, Adachi R, Lee DM, Stevens RL: Essential role for mast cell tryptase in acute experimental colitis. Proc Natl Acad Sci U S A 2011;108:290-295.

14 McNeil HP, Shin K, Campbell IK, Wicks IP, Adachi R, Lee DM, Stevens RL: The mouse mast cell-restricted tetramer-forming tryptases mouse mast cell protease 6 and mouse mast cell protease 7 are critical mediators in inflammatory arthritis. Arthritis Rheum 2008;58:2338-2346.

15 Shin K, Nigrovic PA, Crish J, Boilard E, McNeil HP, Larabee KS, Adachi R, Gurish MF, Gobezie R, Stevens RL, Lee DM: Mast cells contribute to autoimmune inflammatory arthritis via their tryptase/heparin complexes. J Immunol 2009;182:647-656.

16 Beckett EL, Stevens RL, Jarnicki AG, Kim RY, Hanish I, Hansbro NG, Deane A, Keely S, Horvat JC, Yang M, Oliver BG, van Rooijen $\mathrm{N}$, Inman $\mathrm{MD}$, Adachi R, Soberman RJ, Hamadi S, Wark PA, Foster PS, Hansbro PM:
A new short-term mouse model of chronic obstructive pulmonary disease identifies a role for mast cell tryptase in pathogenesis. J Allergy Clin Immunol 2013;131:752-762.

17 Gosman MM, Postma DS, Vonk JM, Rutgers B, Lodewijk M, Smith M, Luinge MA, Ten Hacken NH, Timens W: Association of mast cells with lung function in chronic obstructive pulmonary disease. Respiratory Res 2008; 9:64.

18 Zhang J, Sun J, Lindholt JS, Sukhova GK, Sinnamon M, Stevens RL, Adachi R, Libby P, Thompson RW, Shi GP: Mast cell tryptase deficiency attenuates mouse abdominal aortic aneurysm formation. Circ Res 2011;108: 1316-1327.

19 Cenac N, Andrews CN, Holzhausen M, Chapman K, Cottrell G, Andrade-Gordon P, Steinhoff M, Barbara G, Beck P, Bunnett NW, Sharkey KA, Ferraz JG, Shaffer E, Vergnolle $\mathrm{N}$ : Role for protease activity in visceral pain in irritable bowel syndrome. J Clin Invest 2007; 117:636-647.

20 Ludidi S, Jonkers D, Elamin E, Pieters HJ, Schaepkens E, Bours P, Kruimel J, Conchillo $J$, Masclee A: The intestinal barrier in irritable bowel syndrome: subtype-specific effects of the systemic compartment in an in vitro model. PLoS One 2015;10:e0123498.

21 Erin EM, Leaker BR, Zacharasiewicz A, Higgins LA, Nicholson GC, Boyce MJ, de Boer P, Jones RC, Durham SR, Barnes PJ, Hansel TT: Effects of a reversible beta-tryptase and trypsin inhibitor (RWJ-58643) on nasal allergic responses. Clin Exp Allergy 2006;36:458464.

22 Ishizaki M, Tanaka H, Kajiwara D, Toyohara T, Wakahara K, Inagaki N, Nagai H: Nafamostat mesilate, a potent serine protease inhibitor, inhibits airway eosinophilic inflammation and airway epithelial remodeling in a murine model of allergic asthma. J Pharmacol Sci 2008; 108:355-363.

23 Sylvin H, Dahlback M, Van Der Ploeg I, Alving K: The tryptase inhibitor APC-366 reduces the acute airway response to allergen in pigs sensitized to Ascaris suum. Clin Exp Allergy 2002;32:967-971.

24 Tremaine WJ, Brzezinski A, Katz JA, Wolf DC, Fleming TJ, Mordenti J, Strenkoski-Nix LC, Kurth MC; AXYS Ulcerative Colitis Study Group: Treatment of mildly to moderately active ulcerative colitis with a tryptase inhibitor (APC 2059): an open-label pilot study. Aliment Pharmacol Ther 2002;16:407-413.

$25 \mathrm{He} \mathrm{S,} \mathrm{Gaça} \mathrm{MD,} \mathrm{Walls} \mathrm{AF:} \mathrm{A} \mathrm{role} \mathrm{for} \mathrm{tryptase}$ in the activation of human mast cells: modulation of histamine release by tryptase and inhibitors of tryptase. J Pharmacol Exp Therap 1998;286:289-297.

26 Walls AF, He S, Teran LM, Buckley MG, Jung KS, Holgate ST, Shute JK, Cairns JA: Granulocyte recruitment by human mast cell tryptase. Int Arch Allergy Immunol 1995;107:372373.

27 Schwartz LB, Bradford TR, Littman BH, Wintroub BU: The fibrinogenolytic activity of pu- rified tryptase from human lung mast cells. J Immunol 1985;135:2762-2767.

28 Johnson P, Ammit A, Carlin S, Armour C, Caughey G, Black J: Mast cell tryptase potentiates histamine-induced contraction in human sensitized bronchus. Eur Respir J 1997; 10:38-43.

29 Ammendola M, Sacco R, Sammarco G, Donato $G$, Montemurro S, Ruggieri E, Patruno R, Marech I, Cariello M, Vacca A, Gadaleta $\mathrm{CD}$, Ranieri G: Correlation between serum tryptase, mast cells positive to tryptase and microvascular density in colo-rectal cancer patients: possible biological-clinical significance. PLos One 2014;9:1-7.

30 Chen L, Schrementi ME, Ranzer MJ, Wilgus TA, DiPietro LA: Blockade of mast cell activation reduces cutaneous scar formation. PLos One 2014;9:1-10.

$31 \mathrm{Lu} \mathrm{J}$, Chen B, Li S, Sun Q: Tryptase inhibitor APC 366 prevents hepatic fibrosis by inhibiting collagen synthesis induced by tryptase/ protease-activated receptor 2 interactions in hepatic stellate cells. Int Immunopharmacol 2014;20:352-357.

32 Roman K, Done JD, Schaeffer AJ, Murphy SF, Thumbikat P: Tryptase-PAR2 axis in experimental autoimmune prostatitis, a model for chronic pelvic pain syndrome. Pain 2014;155: 1328-1338.

33 Isozaki Y, Yoshida N, Kuroda M, Handa O, Takagi T, Kokura S, Ichikawa H, Naito Y, Okanoue T, Yoshikawa T: Anti-tryptase treatment using nafamostat mesilate has a therapeutic effect on experimental colitis. Scand J Gastroenterol 2006;41:944-953.

34 Mori S, Itoh Y, Shinohata R, Sendo T, Oishi R, Nishibori M: Nafamostat mesilate is an extremely potent inhibitor of human tryptase. J Pharmacol Sci 2003;92:420-423.

35 Yoshida N, Isozaki Y, Takagi T, Takenaka S, Uchikawa R, Arizono N, Yoshikawa T, Okanoue T: Anti-tryptase therapy in inflammatory bowel disease. Aliment Pharmacol Ther 2006; 2:249-255

36 Marech I, Ammendola M, Gadaleta C, Zizzo N, Oakley C, Gadaleta CD, Ranieri G: Possible biological and translational significance of mast cells density in colorectal cancer. World J Gastroenterol 2014;20:8910-8920.

37 Marech I, Ammendola M, Sacco R, Capriuolo GS, Patruno R, Rubini R, Luposella M, Zuccala V, Savino E, Gadaleta CD, Ribatti D, Ranieri G: Serum tryptase, mast cells positive to tryptase and microvascular density evaluation in early breast cancer patients: possible translational significance. BMC cancer 2014; 14:534.

38 Ranieri G, Ammendola M, Patruno R, Celano G, Zito FA, Montemurro S, Rella A, Di Lecce V, Gadaleta CD, Battista De Sarro G, Ribatti D: Tryptase-positive mast cells correlate with angiogenesis in early breast cancer patients. Int J Oncol 2009;35:115-120.

39 Ribatti D, Crivellato E: Mast cells, angiogenesis, and tumour growth. BBA Mol Basis Dis 2012;1822:2-8 
40 Rice KD, Tanaka RD, Katz BA, Numerof RP, Moore WR: Inhibitors of tryptase for the treatment of mast cell-mediated diseases. Curr Pharm Des 1998;4:381-396.

41 Burgess LE, Newhouse BJ, Ibrahim P, Rizzi J, Kashem MA, Hartman A, Brandhuber BJ, Wright CD, Thomson DS, Vigers GP, Koch K: Potent selective nonpeptidic inhibitors of human lung tryptase. Proc Natl Acad Sci U S A 1999;96:8348-8352.

42 Krishna MT, Chauhan A, Little L, Sampson K, Hawksworth R, Mant T, Djukanovic R, Lee T, Holgate S: Inhibition of mast cell tryptase by inhaled APC 366 attenuates allergen-induced late-phase airway obstruction in asthma. J Allergy Clin Immunol 2001;107:1039-1045.

43 Caughey GH, Raymond WW, Bacci E, Lombardy RJ, Tidwell RR: Bis(5-amidino-2-benzimidazolyl)methane and related amidines are potent, reversible inhibitors of mast cell tryptases. J Pharmacol Exp Ther 1993;264:676-682.

44 Liang G, Choi-Sledeski YM, Chen X, Gong Y, MacMillan EW, Tsay J, Sides K, Cairns J, Kulitzscher B, Aldous DJ, Morize I, Pauls HW: Dimerization of beta-tryptase inhibitors, does it work for both basic and neutral P1 groups? Bioorg Med Chem Lett 2012;22:3370-3376.

$45 \mathrm{He} \mathrm{S}$, Aslam A, Gaca MD, He Y, Buckley MG, Hollenberg MD, Walls AF: Inhibitors of tryptase as mast cell-stabilizing agents in the human airways: effects of tryptase and other agonists of proteinase-activated receptor 2 on histamine release. J Pharmacol Exp Therap 2004;309:119-126.

46 Rice KD, Gangloff AR, Kuo EY, Dener JM, Wang VR, Lum R, Newcomb WS, Havel C, Putnam D, Cregar L, Wong M, Warne RL: Dibasic inhibitors of human mast cell tryptase. Part 1:synthesis and optimization of a novel class of inhibitors. Bioorg Med Chem Lett 2000;10:2357-2360.

47 Selwood T, Elrod KC, Schechter NM: Potent bivalent inhibition of human tryptase-beta by a synthetic inhibitor. Biol Chem 2003;384: $1605-1611$.

48 Nimishakavi S, Raymond WW, Gruenert DC, Caughey GH: Divergent inhibitor susceptibility among airway lumen-accessible tryptic proteases. PLoS One 2015;10:e0141169.

49 Levell J, Astles P, Eastwood P, Cairns J, Houille O, Aldous S, Merriman G, Whiteley B, Pribish J, Czekaj M, Liang G, Maignan S, Guilloteau JP, Dupuy A, Davidson J, Harrison T, Morley A, Watson S, Fenton G, McCarthy C, Romano J, Mathew R, Engers D, Gardyan M, Sides K, Kwong J, Tsay J, Rebello S, Shen L, Wang J, Luo Y, Giardino O, Lim HK, Smith
K, Pauls H: Structure based design of 4-(3-aminomethylphenyl)piperidinyl-1-amides: novel, potent, selective, and orally bioavailable inhibitors of beta II tryptase. Bioorg Med Chem 2005;13:2859-2872.

50 Butterfield JH, Weiler D, Dewald G, Gleich GJ: Establishment of an immature mast cell line from a patient with mast cell leukemia. Leuk Res 1988;12:345-355.

51 Osman IA, Garrett JR, Smith RE: Enzyme histochemical discrimination between tryptase and chymase in mast cells of human gut. J Histochem Cytochem 1989;37:415-421.

52 Garton AJ, Crew AP, Franklin M, Cooke AR, Wynne GM, Castaldo L, Kahler J, Winski SL, Franks A, Brown EN, Bittner MA, Keily JF, Briner P, Hidden C, Srebernak MC, Pirrit C, O'Connor M, Chan A, Vulevic B, Henninger D, Hart K, Sennello R, Li AH, Zhang T, Richardson F, Emerson DL, Castelhano AL, Arnold LD, Gibson NW: OSI-930:a novel selective inhibitor of Kit and kinase insert domain receptor tyrosine kinases with antitumor activity in mouse xenograft models. Cancer Res 2006;66:1015-1024.

53 Denmark SE, Regens CS: Palladium-catalyzed cross-coupling reactions of organosilanols and their salts: practical alternatives to boron- and tin-based methods. Acc Chem Res 2008;41:1486-1499.

54 Grabowsky S, Hesse MF, Paulmann C, Luger $\mathrm{P}$, Beckmann J: How to make the ionic Si-O bond more covalent and the Si-O-Si linkage a better acceptor for hydrogen bonding. Inorg Chem 2009;48:4384-4393.

55 Weinhold F, West R: The nature of the silicon-oxygen bond. Organometallics 2011;30: 5815-5824.

56 Erba F, Fiorucci L, Pascarella S, Menegatti E, Ascenzi P, Ascoli F: Selective inhibition of human mast cell tryptase by gabexate mesylate, an antiproteinase drug. Biochem Pharmacol 2001;61:271-276.

57 Tacke R, Schmid T, Merget M: The SiOH-containing alpha-amino acid $\mathrm{HOMe} 2 \mathrm{SiCH} 2 \mathrm{CH}$ $(\mathrm{NH} 2) \mathrm{COOH}$ and its immobilization on silica via an Si-O-Si linkage. Organometallics 2005; 24:1780-1783.

58 Li E, Zhang J, Wang J, Gao F, Yang Z, Meng Q, Zhang Q, Li N, Huang M, Spengler G, Molnar J, Wang Q: Prevention of VP-16 resistance by a disiloxane, SILA409: effects of SILA 409 on the expression of GRP78 in NCIH446 human small cell lung cancer cells. Lett Drug Des Discov 2011;8:691-697.

59 Molnar J, Mucsi I, Nacsa J, Hever A, Gyemant N, Ugocsai K, Hegyes P, Kiessig S, Gaal D,
Lage H, Varga A: New silicon compounds as resistance modifiers against multidrug-resistant cancer cells. Anticancer Res 2004;24: 865-871.

60 Barany F, Pingle M, Bergstrom D, Giardina SF: US 08853185 Coferons and Methods of Making and Using Them. Cornell University, Purdue Research Foundation, 2014.

61 Levi-Schaffer F, Piliponsky AM: Tryptase, a novel link between allergic inflammation and fibrosis. Trends Immunol 2003;24:158-161.

62 Monument MJ, Hart DA, Befus AD, Salo PT, Zhang M, Hildebrand KA: The mast cell stabilizer ketotifen reduces joint capsule fibrosis in a rabbit model of post-traumatic joint contractures. Inflamm Res 2012;61:285292.

63 Thakurdas SM, Melicoff E, Sansores-Garcia L, Moreira DC, Petrova Y, Stevens RL, Adachi $\mathrm{R}$ : The mast cell-restricted tryptase mMCP-6 has a critical immunoprotective role in bacterial infections. J Biol Chem 2007;282:2080920815.

64 Akers IA, Parsons M, Hill MR, Hollenberg MD, Sanjar S, Laurent GJ, McAnulty RJ: Mast cell tryptase stimulates human lung fibroblast proliferation via protease-activated receptor-2. Am J Physiol Lung Cell Mol Physiol 2000;278:L193-L201.

65 Ruoss SJ, Hartmann T, Caughey GH: Mast cell tryptase is a mitogen for cultured fibroblasts. J Clin Invest 1991;88:493-499.

66 Sommerhoff CP: Mast cell tryptases and airway remodeling. Am J Respir Crit Care Med 2001;164:S52-S58.

67 Mammen M, Choi S-K, Whitesides GM: Polyvalent interactions in biological systems: implications for design and use of multivalent ligands and inhibitors. Angew Chem Int Ed 1998;37:2754-2794.

68 Liang G, Choi-Sledeski YM, Shum P, Chen X, Poli GB, Kumar V, Minnich A, Wang Q, Tsay J, Sides K, Kang J, Zhang Y: A beta-tryptase inhibitor with a tropanylamide scaffold to improve in vitro stability and to lower hERG channel binding affinity. Bioorg Med Chem Lett 2012;22:1606-1610.

69 Schaschke N, Dominik A, Matschiner G, Sommerhoff CP: Bivalent inhibition of betatryptase: distance scan of neighboring subunits by dibasic inhibitors. Bioorg Med Chem Lett 2002;12:985-988.

70 Tamura Y, Hirado M, Okamura K, Minato Y, Fujii S: Synthetic inhibitors of trypsin, plasmin, kallikrein, thrombin, C1r-, and C1 esterase. Biochim Biophys Acta 1977;484:417422. 